\title{
Mental Imagery Applicative Model for Beginner Badminton Coaches
}

\author{
Yusuf Hidayat*, Komarudin, Tri Martini \\ Faculty of Sport Education and Health, Universitas Pendidikan Indonesia, Bandung, Indonesia
}

Received April 23, 2021; Revised June 16, 2021; Accepted July 22, 2021

\section{Cite This Paper in the following Citation Styles}

(a): [1] Yusuf Hidayat, Komarudin, Tri Martini, "Mental Imagery Applicative Model for Beginner Badminton Coaches," International Journal of Human Movement and Sports Sciences, Vol. 9, No. 4A, pp. 59 - 65, 2021. DOI: 10.13189/saj.2021.091310.

(b): Yusuf Hidayat, Komarudin, Tri Martini (2021). Mental Imagery Applicative Model for Beginner Badminton Coaches. International Journal of Human Movement and Sports Sciences, 9(4A), 59 - $65 . \quad$ DOI: 10.13189/saj.2021.091310.

Copyright $(2021$ by authors, all rights reserved. Authors agree that this article remains permanently open access under the terms of the Creative Commons Attribution License 4.0 International License

\begin{abstract}
The implementation of mental imagery in the badminton sport coaching is often neglected, especially for beginner badminton coaches. As an integral part of psychological skill training (PST), the intervention of mental imagery could be conducted in education and training programs. The objective of the study is to help improve the knowledge, attitude, and skill of badminton coaches of the beginners about how mental imagery could be integrated in the training process. The program was conducted in a workshop and coaching practical training involving 20 beginner badminton coaches and 56 beginner student-athletes aged $10-13$. The results of the analysis showed that the education and training program were successful on improving knowledge, attitude, and skill of the badminton coaches for beginners regarding the implementation of integrating mental imagery in a training process. Hence, it can be concluded that the applicable conceptual framework of using mental imagery developed in this study can be used as an applicative model for implementing mental imagery programs in an integrated manner with the training process.
\end{abstract}

Keywords Badminton, Beginner, Coaches, Mental Imagery

\section{Introduction}

In Indonesia, psychological skill training (PST) coaching in sports activities is still being neglected, including in badminton. At present, coaching at the club, school, or education and training center level is still more focused on fostering physical, technical and tactical aspects [1,2], while coaching psychological aspects is still neglected. In fact, the coaching and development of these four aspects must be carried out simultaneously $[3,4]$.

Several components of psychological strategies that play a crucial role in sports activities include goal setting (GS), self-talk (ST), mental imagery (MI), and relaxation [5]. MI is defined as the process of creating or re-creating an experience in the mind [6,7], and is one of the most widely used psychological strategies in sports [8], it is not only effectively used for the mastery of sport skills, but also on the development of psychological skills.

As an integral part of the PST [9], MI must be mastered by the coaches, not only because of the important role of the coach during the training and competition process as the key model [10], but also because of MI's crucial role in enhancing learning, sports performance, and psychological skill development. Therefore, the coach is one of the key elements that can determine the success of PST. In such a constellation of roles, coaches must have sufficient knowledge, attitudes and skills to be able to implement various PST strategic programs, including implementing a program of mental imagery intervention (PMII). PMII development must start from the coach, and one way is through the development of an Education and Training Program (ETP).

Theoretically, PMII is based on two main functions of MI, namely cognitive-MI and motivational-MI functions 
[11]. Cognitive-MI can be divided into cognitive specific MI (CS-MI) and general cognitive MI (GC-MI), while motivational-MI can be divided into specific motivational (SM-MI), motivational general-arousal (MGA-MI) and motivational general-mastery/MGM- MI $[11,12]$.

PMII can only be implemented if the trainer has sufficient knowledge, attitude, and skills about PMII and what and how PMII can be implemented. One of the efforts that can be done is holding an ETP as had been conducted by other researchers $[10,13,14]$. Of course, its implementation must be specific and consider the characteristics of each sport [15] including badminton.

Considering the aforementioned points, the intervention program is designed in the form of workshops and CPT. The ETP of PMII was simulated on 56 student badminton athletes aged 10-13 years. Although taking into account the characteristics of the participants (children's age and beginner group), it has not yet been specifically assessed regarding the sub-functions of the two MI functions [16]. Hence, the ETP of PMII is based on the objective (1) to help improve the knowledge, attitudes, and skills of beginner badminton coaches in West Java about PMII, and (2) to produce an applicative MI model that can be used by beginner badminton coaches to be integrated into their daily training program.

\section{Methods}

\section{Participants}

The ETP of PMII participants consisted of 20 coaches, aged 22-33 years $\left(\mathrm{M}_{\text {years }}=27.8 ; \mathrm{SD}=1.27\right)$, from 12 badminton schools / clubs in West Java Province. There were 56 student-athlete participants, aged between 10-13 years $\left(\mathrm{M}_{\text {years }}=11.2 ; \mathrm{SD}=.55\right)$, consisting of 28 male novice athletes $\left(\mathrm{M}_{\text {years }}=11.4 ; \mathrm{SD}=1.20\right)$, and 28 female novice athletes $\left(M_{\text {years }}=11.0 ; \mathrm{SD}=.46\right)$, came from four badminton schools / clubs in Bandung. All student-athlete participants were selected and determined using disproportional stratified sampling technique [17] and divided into five groups.

\section{Measurement}

Workshop materials. Workshop materials were developed in the form of modules and PMII structures. The validation process is carried out by the Expert Judgment Panel (EJP) in the field of badminton expertise, learning media, language, sports psychology, sports pedagogy, and ETP of PMII participants on the eligibility criteria for content, presentation, and language $[18,19]$. The feasibility level for the module based on the EJP's assessment was between $62 \%-91 \%$, while based on the responses from the ETP of PMII participants, the eligibility rate was $76 \%-92 \%$ (table 1)
Table 1. Module eligibility level based on EJP and workshop participants' assessment

\begin{tabular}{ccccc}
\hline \multirow{2}{*}{ Validator } & \multicolumn{4}{c}{ Eligibility Component (\%) } \\
\cline { 2 - 5 } & Content & Display & Languange & Total \\
\hline $\begin{array}{c}\text { Expert } \\
\text { judgement panel }\end{array}$ & 79.69 & 84.49 & 82.00 & 82.06 \\
\hline $\begin{array}{c}\text { Workshop } \\
\text { participants }\end{array}$ & 84.67 & 83.19 & 86.18 & 84.68 \\
\hline Eligibility average & 82.18 & 83.84 & 84.09 & 83.37 \\
\hline
\end{tabular}

Workshop results. Cognitive ability test. This test is used to measure the trainer's level of mastery of PMII material (content objective) received during the ETP on the cognitive behavioral component (educational objective) of remembering, understanding, applying, analyzing, and assessing $[20,21]$. The five dimensions are developed in 50 multiple choice questions compiled from three modules and seven training activity materials. Based on the results of the split half reliability estimation analysis, the reliability coefficient index of the Spearman-Brown Propecy $=.84$ was obtained.

Self-interest scale. Participants' self-interest affective response to the implementation of ETP of PMII was measured using a self-interest scale in two questions $[10,16]$ "What do you feel when you participate in this ETP activity (happy, normal, less happy, not happy)", and "what do you think about this ETP activity (interesting, casual, less interesting, boring).

Self-confidence scale. The response to the level of confidence or trust of participants in their ability to succeed in implementing PMII in the badminton basic skill (BBS) training process was measured using a modified version of the Self-Confidence Scale / SCS [22]. Compiled by items of cognitive efficiency dimension (CE-D), technique and physical dimension (TP-D), and resilience/RD [23]. SCS internal consistency reliability has a Cronbach SCS Alpha coefficient index of .92, .76 for CE-D, .71 for TP-D, and .79 for RD.

Results of Coaching Practical Training (CPT). CPT Observation. To determine the skill level of ETP of PMII participants in applying the PMII concept in the BBS training process, the CPT Observation instrument is used $[10,14]$. The observation dimension is based on the dimensions of the stages of the sport skills learning process, namely the opening, core training, and closing activity stages $[2,16,24,25]$ and elaborated into nine out of 14 categories (indicators) training behavior developed in the Arizona State University Observation Instrument or ASUOI [26-28], namely pre-intruction indicators, concurrent instruction, post instruction, questioning, manual manipulation, positive modelling, hustle, praise, management. These indicators are assessed as absolute checklist type on a scale of 0 or 1 . Each indicator of the coaches' behavior when training is assessed using the absolute rating of the checklist type on a dichotomous scale of 0 or 1 .

The results of the analysis of Lawshe's content validity 
ratio (CVR) obtained a content validity coefficient index $(\mathrm{CVCI})$ between .60-1.00. Overall CVCI $=.90$ (94.9\%), .83 (91.4\%) for opening activities, .89 (94.3\%) for core training activities, and .98 (99\%) for closing activities. Based on the analysis of the one way ANOVA (interclass correlation coefficient/ICC) analysis, the overall reliability coefficient index between observers was $.92, .97$ for opening activities, .86 for core training activities, and .98 for closing activities.

\section{Procedure}

ETP of PMII is carried out in the form of workshops and CPT activities. Workshops are face-to-face activities in class in the form of lectures, questions and answers, discussions, and simulations or role-playing. Meanwhile, CPT is a mastery activity in the field $[6,10,16,29]$ in the form of training practice. The procedure for these two activities is described as follows:

Each participant takes part in a workshop for four days to conduct studies, simulations, exercises to compile, develop, and apply PMII in the BBS daily training program. The study materials consisted of a BBS analysis workshop (first day), a workshop on the basics of PMII theory and its application to young athletes (second day), a workshop on PMII learning approaches and structures (third day), MI and CPT workshops (fourth day). The workshop process is carried out in four stages [30], namely the experience formation stage (a participant is involved in activities with other participants), reflection (rethinking his experience of involvement and trying to find its meaning), concept formation (the process of interpreting their involvement in activities), and concept testing (dialogical and multi-logical processes between participants and facilitators regarding the concepts that have been formed so that they produce concepts that (maybe) are different from existing concept designs). All documents produced from the workshop process are used as references for the implementation of the CPT. Each participant takes a cognitive ability test before the workshop starts (pre-test), at the end of the workshop (post-test 1), and after CPT (post-test 2).

CPT is a training activity to act as a coach in the training process [10]. The main objective of the CPT is to apply the concepts and theories of PMII according to the functions and sub-functions of MI. In this CPT activity, participants were divided into five groups according to the MI sub-function, namely CS-MI (G-1), CG-MI (G-2), MS-MI (G-3) MGA-MI (G-4), and MGM-MI (G-5). Each group consisted of six people (three pairs of trainers) and all CPT groups received a combination of PIMI and BBS treatment. CPT is held for four meeting days, the first day for joint training under the coordination of the facilitator, and the last three days for CPT for each group. The duration of each CPT is 130 minutes [16]. There are three pairs of coaches in each group, and each pair of coaches acts as a coach and the other coaches are tasked with being an observer.

\section{Results}

The success of ETP of PMII is determined based on outcome and product criteria. The outcome criteria consist of cognitive abilities, self-interest, and self-confidence of participants, while the product criteria are in the form of an applicative document (tutorial module) of PMII in the BBS training process. The results of the analysis for the cognitive ability test showed that there was a change in the participant's level of mastery of the ETP of PMII material between each test time (tables 2 and 3 ).

Table 2. Descriptive Statistics of Coaches Cognitive Ability Tests Related to ETP of PMII

\begin{tabular}{ccccc}
\hline \multirow{2}{*}{ Compulsory Test Time } & \multicolumn{4}{c}{ Cognitive Ability Test Score } \\
\cline { 2 - 5 } & M & SD & SE & $\%$ \\
\hline Pre-test (before the workshop) & 38.01 & 3.86 & .97 & 38.00 \\
\hline Post-test 1 (after the workshop) & 59.76 & 7.94 & 1.38 & 61.50 \\
\hline Post-test 2 (after CPT) & 74.89 & 6.27 & 1.10 & 76.40 \\
\hline
\end{tabular}

note: $\mathrm{M}=$ Mean; $\mathrm{SD}=$ Standard deviations; $\mathrm{SE}=$ Standard error

Table 3. One way ANOVA Result of Cognitive Ability Test for ETP of PMII Trainers

\begin{tabular}{ccccc}
\hline Variable & & df & F & P value \\
\hline Cognitive ability & Between Groups & 2 & 140.55 & .00 \\
& Within Groups & 45 & & \\
& Total & 47 & & \\
\hline
\end{tabular}

Note: $\mathrm{p}<.05 ; \mathrm{p}<.01$

Mastery of participants on post-test $2(76.40 \%)$ was higher than that of post-test $1(61.50 \%)$ and pre-test $(38.00 \%)$, and mastery of participants on post-test 1 was higher than that of the pre-test. The one-way ANOVA results showed that there was a significant difference in the participants 'level of knowledge about PMII between each test time $(\mathrm{F}(2.45)=140.55, \rho=.00<.05(\alpha)$. Participants' knowledge on post-test $2(\mathrm{M}=74.89 ; \mathrm{SD}=$ 6.27) was higher and significant than the post-test $1(\mathrm{M}=$ 59.76; $\mathrm{SD}=7.94)$ and the pre-test $(\mathrm{M}=38.01 ; \mathrm{SD}=3.86)$, the knowledge of the participants in the post test $1(\mathrm{M}=$ 59.76; $\mathrm{SD}=7.94$ ) was higher and significant than during the pre-test $(\mathrm{M}=38.01 ; \mathrm{SD}=3.86)$. As for the effectivity response, the results of the analysis are presented in table 4, as follows: 
Table 4. Affection response of ETP of PIMI participants in the workshop and CPT process

\begin{tabular}{cccccccc}
\hline \multirow{2}{*}{ ETP of PMII activities } & \multicolumn{3}{c}{ Affection Response } \\
\cline { 2 - 8 } & Happy & Interesting & Total & CE-D & TP-D & R-D & TOTAL \\
\cline { 2 - 8 } & $90 \%$ & $82 \%$ & $86 \%$ & $89 \%$ & $86 \%$ & $86 \%$ & $87 \%$ \\
\hline workshop process & $86 \%$ & $89 \%$ & $87,5 \%$ & $91 \%$ & $88 \%$ & $88 \%$ & $89 \%$ \\
CPT process & $88 \%$ & $83.5 \%$ & $86.75 \%$ & $90 \%$ & $87 \%$ & $87 \%$ & $88 \%$ \\
Total & & & &
\end{tabular}

According to the table 4, the findings on affection responses for both self-interest and self-confidence aspects strengthen the results of cognitive abilities. The level of achievement in both aspects in both the workshop process and the CPT process was above $85 \%$, both as a whole and in each indicator.

Based on the workshop process, six applicable documents that underlie and will be used in CPT activities. This document is a refinement of existing documents [16]. The refinement result document referred to is the PMII tutorial module in the BBS training process, consisting of six sub modules, namely: (1) BBS analysis (description of BBS stages for the benefit of learning, analysis and sources of BBS movement errors, and BBS learning strategies), (2) the application of Social Cognitive Theory (SCT) and Action Theory Approach in PMII, as the two main theories that underlie PMII (3) the basics of PMII training design for students-beginner athletes aged 10-13 years, (4) PMII learning stages based on social cognition approach: observation, imitation, self-control, and self-regulation, (5) PMII learning structure: opening, core training, and closing, and (6) MI strategy training and simulation (an applicative conceptual framework of MI in the BBS training process). With regard to MI strategy exercises and simulations, a product is produced in the form of an applicable MI conceptual framework, as follows:

- At the beginning of each MI training session, participants are in a relaxed state, anatomically supine position or anatomical sitting position on the badminton court;

- Each training session begins with a basic MI exercise;

- The conceptual approach used is the conceptual framework of MI "Four Ws" / "Where, When, What, and Why"[31,32]) and "How"[9].

- MI can be used during training situations, namely before, during, and after core training (where and when), for cognitive-MI and motivational-MI functions related to BBS learning / training (why). A MI training session $\leq 10$ minutes, in the positive-MI form, aimed at the dimensions of vividness and control ability, conducted from a visual-external (before) and kinaesthetic-internal (after) training perspective

- The object imagined in Cognitive-MI is part by part of the movement, the whole series of movements, and the result of the blow from the shuttlecock which will and has been hit both in the direction of flight and its height until it falls in the target area, while the object imagined in motivational-MI is specific goals and activities related to goals, situations when controlling tension, and situations when successfully displaying movements properly in accordance with predetermined goals (what);

- MI through tape-recorder media, using cues which function as a stimulus for the imagined object in accordance with the applicable concept of the BBS construct, and written using the layering system method (how).

The following is an example of a workshop process for the MI application concept in relation to the BBS training process, as one of the documents produced for use in the CPT.

\section{- Stage 1: Experience formation}

Each participant in each group examines the applicable concepts of MI in BBS exercises (each one group studies the unit on basic concepts and simulations of SC-MI, GC-MI, MS-MI, MGA-MI, and MGM-MI

\section{- Stage 2: Reflection}

Each participant reflects on all the material he has learned and writes the material in relation to the type of MI (what), its function (why), the situation and conditions for applying it in the training process (when, where, and how), both for SC-MI, GC-MI, MS-MI, MGA-MI, and MGM- MI

\section{- Stage 3: Concept formation}

The results of the reflection of each group member are discussed in their respective groups for further study with the results of other group reflections to produce the MI application concept related to when and under what conditions MI is used, what objects or events are imagined, what function is it for, and how is the process. These results will be presented at the concept testing stage in front of the facilitator and other groups.

\section{- Stage 4: Concept Testing}

Each group presented the applicable concept it produced to get responses and input from the facilitator and other groups to produce an applicable concept as a 
hypothetical model of MI in the BBS training process, when and under what conditions MI was used, what objects or events were imagined, what function was it for, and how is the process

The same workshop process was also carried out for other study materials, and the results were used as a reference for the implementation of the CPT as an applicable PMII concept to be applied in the BBS training process. As for CPT observation, the results of the analysis are presented in table 5 .

Table 5. Descriptive Statistics of CPT Observation Analysis Results

\begin{tabular}{cccc}
\hline Observation Dimensions & M & SD & $\%$ \\
\hline Opening Activity Stage & .86 & .07 & 86.00 \\
The Core Training Activity Stage & .70 & .15 & 70.60 \\
Closing Activity Stage & 1.00 & .33 & 100.00 \\
Overall average & .85 & .40 & 85.53 \\
\hline
\end{tabular}

In accordance with table 5, the overall results of mastery of applying training skills were $85.53 \%, 86.00 \%$ for opening activities, $70.60 \%$ for core training activities, and $100 \%$ for closing activities. The two indicators that obtained the lowest level of achievement were the indicators of skills in asking questions about movement techniques $(8 \%)$ and managing student-athlete movement tasks $(32.80 \%)$.

\section{Discussion}

The success of ETP of PMII activities is measured based on outcome and product criteria. The ETP of PMII results relate to the level of mastery of participants in cognitive aspects (descriptive and procedural knowledge about PMII concepts and strategies in the BBS training process), affective (self-interest and self-confidence) and psychomotor (practical skills to apply PMII in CPT activities). The test results on the knowledge aspect showed an increase from the time of pre-test, post-test 1, and post-test 2 . The knowledge of the participants in the post-test 2 was higher than that of the post-test 1 and pre-test, the knowledge of the participants in the post-test 1 was higher than the pre-test.

In accordance with these results, ETP was proven to be effective in improving the participants' cognitive abilities related to the concepts and strategies for implementing PMII in BBS training. The coaches have sufficient knowledge about the concepts and strategies for implementing PMII and integrate it into the BBS training program for student athletes and beginner children aged 10-13 years. The results on this aspect of knowledge implicitly indicate a coherence between complementary and reinforcing material substances and the methodology used. In one constellation, the workshop material is relevant to the real problems, demands and needs faced by coaches in the field, and is strengthened by an interactive workshop process (dialogical and multilogical) which is able to generate learning processes in other constellations.

Likewise the results on the affective aspect, the results on the aspect of knowledge are corroborated by the results on the affective aspect, in general the participants respond happily to the workshop process and give a response that the workshop process is interesting. Likewise with the results of the participants' level of confidence in their ability to successfully apply PMII in the BBS training process, in general the participants felt confident that they could apply PMII in the BBS training process.

The material presented is not only in a dynamic process through focused and in-depth discussions, simulations, and role-playing, but is also complemented by concrete examples that connect concepts that must be understood with applicable demands in the field. In other words, the material is presented in a ETP scenario that is "in a user friendly manner" [33], which not only makes the abstraction of material more concrete and meaningful but is also provided through a dynamic and interactive process capable of being evoke the occurrence of the training process.

The CPT observation results reinforce the workshop results which are measured based on the level of implementation of each indicator of training skills at each stage of the PMII learning structure with the amount of achievement above $80 \%$. These results indicate a synergy between the achievement in the aspects of cognitive and affective abilities with the success (skills) of implementing PMII in the process of BBS training. Furthermore, these synergistic results can be used as conceptual-practical provisions to be applied in the actual training process.

The applicable conceptual framework for MI as a workshop product is needed for the development of MI scripts. Referring to the product and the characteristics of novice athlete students aged 10-13 years, the MI script is written using the layering system method [34], a script modification method to adjust to changes in athletes' emotions, skill levels, environment in which they appear, and abilities, imagination of athletes [35], which allows student-athlete beginners to gradually more experience imagine their imagination.

The MI script format is developed in three parts, namely the introduction, main, and closing sections [14]. Furthermore, the applicable conceptual framework and MI scripts that have been developed are integrated into the overall structure of the training program plan, namely in the opening activity stage, between core training activity, and the closing activity stage in accordance with the proposition of initial consolidation and final consolidation in implementing MI [16,36]. For applicative purposes, the PMII plan that has been designed needs to be introduced to student-athletes to provide initial knowledge and understanding of the concepts and strategies for implementing MI in the training process. As with other 
PST strategies, PMII development will be more effective when the product is the result of collaboration between coaches with athletes.

The main result of this ETP is in the form of a "hypothetical product" whose constraints need to be further tested in the actual training process, while still being monitored and evaluated periodically for its implementation, because it is believed that training is an effective tool to achieve the goals of education and training [37], so that it is carefully known the level of development, as well as finding various obstacles and difficulties that may be faced when implementing it as well as social feedback for the development of the next program.

\section{Conclusion}

In general, the coaches felt and believed the benefits of his involvement in ETP of PMII. Knowledge and affection response (self-interest and level of expertise) increases, as well as skills in applying PMII in the process of BBS training. PMII can be used as a hypothetical model for mental training strategies in the BBS training process for novice athletes aged 10 to 13 years old. In accordance with the hypothetical product produced through ETP, here are some steps to apply PMII in the training process: (1) developing an applicative framework according to the characteristics of athletes (2) compiling and developing MI scripts using certain methods according to athlete's characteristics, (3) integrating the applicable framework into the overall structure of the lesson plan, and (4) communicating PMII to student-athletes in accordance with the applicable conceptual framework that has been developed.

\section{Acknowledgments}

The authors would like to thank all those who have helped this ETP, especially badminton coaches at badminton clubs or schools in Bandung City, the Faculty of Sport Education and Health, and the Institute for Research and Community Service, Universitas Pendidikan Indonesia, who have funded this study.

\section{REFERENCES}

[1] Hidayat Y, Budiman D. The influence of self-talk on learning achievement and self confidence. Asian Social Science. 2014 Mar 1;10(5):186. http://dx.doi.org/10.5539/a ss.v10n5p186

[2] Hidayat Y, Sukatdiyanto. The Analysis of Mental Imagery Functions in Badminton for Novice Athletes. IJCTA. 2016; 9(35):191-205.
[3] Blumenstein B, Lidor R. The road to the Olympic Games: A four-year psychological preparation program. Athletic insight. 2007 Dec;9(4):15-28. http://www.athleticinsight.c om/Vol9Is

[4] Lidor R, Blumenstein B, Tenenbaum G. Psychological aspects of training in European basketball: conceptualization, periodization, and planning. The Sport Psychologist. 2007 Sep 1;21(3):353-67. DOI: 10.1123/TSP.21.3.353

[5] Thelwell RC, Greenlees IA. Developing competitive endurance performance using mental skills training. The Sport Psychologist. $2003 \quad$ Sep 1;17(3):318-37. DOI:10.1123/TSP.17.3.318

[6] Vealey RS, Greenleaf CA. Seeing is believing: Understanding and using imagery in sport. Applied sport psychology: Personal growth to peak performance. 2001; 4:247-72.

[7] Vealey RS, Forlenza ST. Understanding and using imagery in sport. Applied sport psychology: Personal growth to peak performance. 2015:240-73.

[8] Vealey, RS. Mental skills training in sport. Handbook of sport psychology. 2007 Oct 5:287.

[9] Weinberg R. Does imagery work? Effects on performance and mental skills. Journal of imagery research in sport and physical activity. 2008 Feb 14;3(1). https://doi.org/10.2202 /1932-0191.1025

[10] Hidayat, Y. Workshop of self-talk intervention for beginner of badminton coaches. Asian Journal of Scientific Research. 2019: 12(2), 263-270. https://scialert.net/abstract/?doi=ajsr .2019.263.270

[11] Paivio A. Cognitive and motivational functions of imagery in human performance. Canadian journal of applied sport sciences. Journal canadien des sciences appliquées au sport. 1985 Dec 1;10(4):22S-8S. https://pubmed.ncbi.nlm.nih.go v/4085129/

[12] Hall CR, Mack DE, Paivio A, Hausenblas HA. Imagery use by athletes: development of the Sport Imagery Questionnaire. International Journal of Sport Psychology. 1998 29, 73-89.

[13] Camire M, Trudel P. Helping youth sport coaches integrate psychological skills in their coaching practice. Qualitative Research in Sport, Exercise, and Health. 2013;6(4), 1-18. https://doi.org/10.1080/2159676X.2013.841281

[14] Harwood C. Developmental consulting in a professional football academy: the $5 \mathrm{Cs}$ coaching efficacy program. The sport psychologist, 2008; 22(1), 109-133.https://doi.org/10. 1123/tsp.22.1.109

[15] Freitas SD, Dias C, Fonseca A. What do coaches think about psychological skills training in soccer? A study with coaches of elite Portuguese teams. International journal of sports science. 2013; 3(3):81-91. http://article.sapub.org/10 .5923.j.sports.20130303.04.html

[16] Hidayat, Y. Pengaruh intervensi psikologis strategi multi-taknik (IPSM) terhadap hasil belajar keterampilan dasar bermain bulutangkis, motivasi olahraga, dan kepercayaan diri. (Disertasi:Tidak dipublikasikan). Psikologi Universitas Gadjah Mada, Yogyakarta. 2016 
[17] Johnshon B, Christensen L. Educational research (4th. ed.) London: SAGE. 2012

[18] Muljono, P. Kegiatan penilaian buku teks pelajaran pendidikan dasar dan menengah. Buletin BSNP. Media Komunikasi dan Dialog Standar Pendidikan. 2006. 2 (1), 14-23.

[19] Sari EA, Sugiyanto R, Tjahjono H. Penilaian kualitas buku teks pelajaran geografi sebagai sumber belajar bagi siswa SMA kelas XI di Kabupaten Temanggung. Edu Geography. 2012. 1 (1), 23-29. https://journal.unnes.ac.id/ sju/index.php/ edugeo/article/view/\%20921

[20] Anderson LW, Bloom BS. A taxonomy for learning, teaching, and assessing: A revision of Bloom's taxonomy of educational objectives. Longman; 2001.

[21] Näsström G. Interpretation of standards with Bloom's revised taxonomy: a comparison of teachers and assessment experts. International Journal of Research \& Method in Education. $\quad 2009 \quad$ Apr $1 ; 32(1): 39-51$. https://doi.org/10.1080/17437270902749262

[22] Hidayat Y, Hambali B. Confirmatory Factor Analysis of the Self Confidence Scale among beginner badminton child athletes: A pilot study. Proceedings of the 2rd International Conference on Sport Science, Health, and Physical Education (ICSSHPE 2017). Scitepress. (2017). 951-956. DOI:10.2991/ icsshpe-18.2019.85

[23] Vealey RS, Chase MA, Horn TS. Advances in sport psychology. Self-confidence in sport: Conceptual and research advances. Champaign, IL. Human Kinetics. 2008.

[24] Suherman, A. Revitalisasi pengajaran dalam pendidikan jasmani. Bandung: CV. Bintang Warli Artika. 2009.

[25] Hidayat Y. The effect of goal setting and mental imagery intervention on badminton learning achievement motor skill at 10-12 years old: The context of Indonesia. EDUCARE. 2011;3(2).DOI https://doi.org/10.2121/edu-ijes.v3i2.233.g232

[26] Lacy AC, Darst PW. Evolution of a systematic observation system: The ASU coaching observation instrument. Journal of Teaching in Physical Education. 1984 Apr 1;3(3):59-66.DOI:10.1123/JTPE.3.3.59

[27] Claxton DB. A systematic observation of more and less successful high school tennis coaches. Journal of Teaching in Physical Education. 1988 Jul 1;7(4):302-10. https://doi.org/10.1123/jtpe.7.4.302
[28] Isabel M, António S, António R, Felismina P, Michel M. A systematic observation of youth amateur volleyball coaches behaviours. International Journal of Applied Sports Sciences. 2008 Dec 1; 20(2): 37-58. https://www. researchgate.net/publication/37656691

[29] Weinberg RS, Gould D. Foundations of sport and exercise psychology, 7E. Human Kinetics; 2018 Nov 16.

[30] Boyett JH, Boyett JT. The guru guide: The best ideas of the top management thinkers. John Wiley \& Sons Inc; 1998 May 20. https://www.wiley.com.

[31] Munroe KJ, Giacobbi PR, Hall C, Weinberg R. The four Ws of imagery use: Where, when, why, and what. The Sport Psychologist. 2000 Jun 1;14(2): 119-37. DOI:https://doi.org/10.1123/tsp.14.2.119

[32] Munroe-Chandler KJ, Hall CR, Fishburne GJ, Strachan L. Where, when, and why young athletes use imagery: An examination of developmental differences. Research quarterly for exercise and sport. 2007 Mar 1;78(2):103-16. https://doi.org/10.1080/02701367.2007.10599408

[33] Gould D, Damarjian N, Medbery R. An examination of mental skills training in junior tennis coaches. The sport psychologist. 1999 Jun 1;13(2):127-43. DOI: https://doi.org/10.1123/tsp.13.2.127

[34] Nordin SM, Cumming J. Professional dancers describe their imagery: Where, when, what, why, and how. The Sport Psychologist. 2005 Dec 1;19(4):395-416. DOI: https://doi.org/10.1123/tsp.19.4.395

[35] Holmes PS, Collins DJ. The PETTLEP approach to motor imagery: A functional equivalence model for sport psychologists. Journal of applied sport psychology. 2001 Jan 1;13(1):60-83. DOI: 10.1080/10413200109339004

[36] Mizuguchi N, Nakata H, Uchida Y, Kanosue K. Motor imagery and sport performance. The Journal of Physical Fitness and Sports Medicine. 2012 May 25;1(1):103-11. DOI:10.7600/jpfsm.1.103.https://www.researchgate.net/pu blication/ 272951671

[37] AL-Haliq M. The Effect of a Training Program Using Speed-Specific Strength Exercises on Sensory-Motor Perception in Learning Stroke Forehand Smash in Badminton Material for Students of the Hashemite University. International Journal of Human Movement and Sports Sciences. 2020 Nov 29; 8(6):299-307.DOI: 10.13189/saj.2020.080601. 